\title{
The Weight of Tax Revenue in the Pakistan Economy
}

by

\section{A.H.M. NURUDDIN CHOWDHURY*}

This paper provides a general review of taxes in Pakistan with special reference to central government tax efforts. The weight of central taxes in national income and in the central budget is analysed using the tax data for the period 1948-62. Some suggestions are made about mobilizing more savings by raising tax revenues.

\section{The Case for Raising the Weight of Tax Revenue}

In the developing countries, we usually find a fiscal system where the relative weight of the public revenues in the total economy is meagre and limited to certain sectors. This state of affairs tends to make fiscal policy weak as well as blunt. As increasing the effectiveness of monetary policy in underdeveloped countries presupposes organization and wide dissemination of monetary institutions, so a prerequisite for an efficacious fiscal policy is enhancement of the influence of taxes in the economy ${ }^{1}$.

Enhancement of the relative importance of taxation in the economy is essential for a number of reasons. First, the governments of the developing countries have to finance increasingly larger development programmes. The safe way to acquire the necessary resources is through taxes, as supply rigidities make flirtation with inflationary finance a dangerous $\mathrm{game}^{2}$. Second, power to tax brings with it the power to regulate. The government can perform its function of guiding the economy along the planned course without excessive reliance on direct controls only if it is adequately armed with effective tax powers which can touch any part of the economy according to the need of circumstances. Third, built-in stabilizers and countercyclical tax adjustments can successfully offset fluctuations in income and employment "where the ratio of taxes to national income is high, a large proportion of revenue is from net income taxes and there is a large foreign

*The author is Staff Economist at the Institute of Development Economics. He is indebted to Dr. John $\mathbf{H}$. Power, Research Adviser at the Institute, for helpful guidance. Drs. M. Akhlaqur Rahman, Senior Economist, and Christoph Beringer, Research Adviser, kindly read an earlier draft and made useful comments.

1. David E. Shirley, "Income Taxes for Lesser Developed Nations", National Tax Journal, Vol. XII, 1959. ("A tax policy that reaches almost the entire population is essential." p. 267).

2. R.N. Bhargava, "Taxation Policy", Public Finance, No. 4, 1959. ("Taxation appears to be the only alternative if inflation is to be avoided". p. 326). 
trade sector subject to ad valorem import and export duties"'. Finally, in the absence of a well-organized capital market, a system of government taxing and lending can help channel savings into development investment.

The considerations set out in the foregoing passages drive home the fact that one of the important fiscal goals of Pakistan should be to enhance government's tax revenues. The present low level of tax revenues in Pakistan contrasts glaringly with the high level reached even in countries at a similar stage of economic development ${ }^{4}$.

\section{A General Perspective of the Tax System in Pakistan}

In August 1947 Pakistan inherited the tax system developed under the British rule in India which was adopted with some modifications. The tax system has some important constitutional features. Taxes are levied by two levels of governments, at the centre and the provinces, each having well-defined jurisdiction within which to exercise their power to tax ${ }^{5}$. Because of the relative inadequacy of the revenue sources wholly given to the provinces, a system of sharing in the proceeds of some important centrally managed taxes has been installed following the recommendation of Sir Jeremy Raisman, one-time finance minister of the undivided India. The tax powers and the relative shares in the proceeds of the taxes currently enjoyed by the central and provincial governments are based, more or less, on the recommendations contained in the Raisman Award of 1951'. In spite of the efforts of this Award to secure an equitable distribution of the sources of revenues, the provinces have to rely heavily on central grantsin-aid, often to meet even a part of their current expenditures. Changes in this scheme have been made from time to time in deference to the changing revenue needs of the various governments and the growth and decay of the various sources?.

A summary idea of the tax structure of Pakistan may be obtained from Table I, which shows the composition of the total tax revenue of central. and provincial governments.

". Richard Goode, "Report of the Indian Taxation Enquiry Commission", National Tax Journal, 1956, p. 139.

4. See, Table III below.

5. Local bodies also have minor powers to tax in their limited jurisdiction.

- For a detailed discussion of the provisions of this Award and the constitutional background, See, J.R. Andrus and A.F. Mohammad, The Economy of Pakistan, (London: Oxford University Press, 1958), pp. 309-310. 1962.

7. The latest of such changes has been proposed by the Central Finance Commission, 


\section{TABLE I}

TOTAL TAX REVENUE OF CENTRAL AND PROVINCIAL GOVERNMENTS AND ITS COMPOSITION

(Rupees in lacs).

Revenue sources

Actuals $1960 / 61$

Income and corporation tax

Land revenue

Customs

Excise duty

61,80

Sales tax

40,21

Miscellaneous

Total :

$2,44,19$

Source: Explanatory Memorandum, Budget of the Government of Pakistan, 1962/63, pp. $204-5$; 224-5; and 228-9.

Of these, most of the land revenue and a number of minor taxes included in the miscellaneous group are collected by the provinces. All other important sources belong to the centre. The provinces get a share of the four major taxes according to a schedule fixed on the basis of the Raisman Award. In 1960/61, the share of the provinces were as follows:

\section{TABLE II}

(Rupees in lacs)

\begin{tabular}{l|c|c}
\hline Name of the tax & Amount & $\begin{array}{c}\text { Per cent of total } \\
\text { collection }\end{array}$ \\
\hline Income tax & 5,87 & 15.3 \\
Customs & 3,55 & 5.7 \\
Excise duty & 5,77 & 14.4 \\
Sales tax & 22,35 & 47.8 \\
Total allocation to provinces & 37,54 & 20.1 \\
Total allocation to East Pakistan & 14,52 & 7.8 \\
Total allocation to West Pakistan & 23,02 & 12.3 \\
\hline
\end{tabular}

Source : Explanatory Memorandum, Budget of the Government of Pakistan, $1962 / 63$, pp. 220-21.

This allocation failed to meet the revenue needs of the provincial governments, especially of East Pakistan. "Because of its emphasis on source 
of collection as a criterion in determining the share of the provinces, East Pakistan got a smaller share. A distribution on the basis of relative size of population, it was thought, might be more satisfactory because source of collection may not be related to the incidence of the taxes, and also because this is more in conformity with federal principles. The recent changes in allocation have taken note of these factors and give a larger share to the provinces.

TABLE II.A

(Rupees in lacs)

Name of the tax

\begin{tabular}{|c|c} 
Amount & $\begin{array}{c}\text { Per cent of total } \\
\text { collection }\end{array}$ \\
\hline
\end{tabular}

Per cent of total

Name of the tax

Customs

Excise duty

Sales tax

Estate duty

Total allocation to provinces

Total allocation to East Pakistan

Total allocation to West Pakistan

Source: Explanatory Memorandum, Budget of the Government of Pakistan, 1962/63, p. 220-1.

Table II.A shows the allocation of centrally collected taxes to the provinces in the budget of $1962 / 63$, which incorporates for the first time the recommendations made by the Central Finance Commission in 1962. The share of the provinces has increased from 21.5 per cent to 32.2 per cent of the total collection. The provinces have now become recipients of shares from corporation tax and, another minor source, estate duty. The share of East Pakistan has been enhanced considerably by the adoption of population ratio of the two provinces, along with source of collection, as a basis for determining their relative shares. The total amount allocated to East Pakistan is slightly more than that allocated to West Pakistan. A distribution made completely on population basis, however, would be in the ratio of $56: 44$ in favour of East Pakistan.

\section{The Burden Asgregate Taxation in the Economy}

Apart from the political and administrative problems of distributing the sources of revenues between the levels of governments, the more intractable and economictlly more significant problem is posed by the persistently low level of the aggregate tax revenue. The position of Pakistan in this 
field compares unfavourably even to that of some of the underdeveloped countries of Asia and the Far East. Table III shows the comparative tax burden in Asian countries for which data is available.

\section{TABLE III}

\section{RELATIVE WEIGHT OF TAXES IN SELECTED COUNTRIES}

\begin{tabular}{l|l|c}
\hline & & $\begin{array}{c}\text { Total tax reve- } \\
\text { nues as percent } \\
\text { of national in- } \\
\text { come }\end{array}$ \\
& & Year \\
\hline Burma & & \\
Cambodia & $1959 / 60$ & 23 \\
Ceylon & 1959 & 15 \\
Federation of Malaya & $1959 / 60$ & 21 \\
India & 1959 & 18 \\
Indonesia & $1959 / 60$ & 10 \\
Japan & 1959 & 6 \\
Republic of Korea & $1959 / 60$ & 14 \\
Pakistan & 1959 & 16 \\
Philippines & $1959 / 60$ & 7 \\
Thailand & $1959 / 60$ & 11 \\
& 1959 & 13 \\
\hline
\end{tabular}

Source: 1) For Pakistan, the estimates of the Second Five Year Plan of Pakistan, 1960-65.

2) All other countries, United Nations, Economic Survey for Asia and Far East, 1961/62, pp. 170; and 211.4.

Figures in Table III clearly show that except for Indonesia, Pakistan ranks lowest in order of relative tax burden borne by the economy. A comparison of the per-capita national income of these countries may be interesting here. The per-capita national income of Burma has been estimated to be 20 dollars less and that for Ceylon to be 40 dollars more than the per-capita national income of Pakistan ${ }^{8}$. But both Burma and Ceylon have mobilized a much higher proportion of their national income in tax revenues. This suggests that per-capita income is not very decisive, at least within this range, in determining what proportion of national income could be raised in taxes.

8. United Nations, Per Capita National Product of Fifty Five Countries: 1952-54, Statistical Papers Series E, No. 4 (New York: 1957); Quoted in B. Higgins, Economic Development, (New York: Norton \& Company Inc., 1959), p.10. 


\section{Share of Direct and Indirect Tares}

Like most underdeveloped countries Pakistan depends heavily on indirect taxes, though this has diminished over the past decade owing to the decline in the importance of customs revenue. In 1949/50, revenue from customs alone constituted over 60 per cent of the central tax revenue though foreign trade constituted only a little over 12 per cent of the national income. Customs revenue formed only 31.2 per cent of centrally collected tax revenues in $1961 / 62$.

In $1959 / 60$, the Planning-Commission estimate places the proportion of direct taxes in the consolidated budget of the central and provincial governments at 33 per cent of total tax revenue. This is compared in Table IV below, with the breakdown of total tax revenue into direct and indirect for all the countries of Table III.

\section{TABLE IV}

\section{WEIGHT OF DIRECT AND INDIRECT TAXES IN SELECTED COUNTRIES}

\begin{tabular}{l|l|c|c}
\hline Name of the country & Year & $\begin{array}{c}\text { Percentage } \\
\text { of } \\
\text { direct taxes }\end{array}$ & $\begin{array}{c}\text { Percentage } \\
\text { of } \\
\text { indirect taxes }\end{array}$ \\
\hline Burma & $1959 / 60$ & 32 & 68 \\
Cambodia & 1959 & 12 & 88 \\
Ceylon & $1959 / 60$ & 19 & 81 \\
Federation of Malaya & 1959 & 18 & 82 \\
India & $1959 / 60$ & 31 & 69 \\
Indonesia & 1959 & 41 & 59 \\
Japan & $1959 / 60$ & 50 & 50 \\
Republic of Korea & 1959 & 26 & 74 \\
Pakistan & $1959 / 60$ & 33 & 67 \\
Philippines & $1959 / 60$ & 22 & 78 \\
Thailand & 1959 & 8 & 92 \\
\hline
\end{tabular}

Source: Same as in Table III.

In Table IV only in Japan and Indonesia is the proportion of direct taxes more than that in Pakistan. Thus, the relative weight of direct taxes in - Pakistan is high in relation to most of the other underdeveloped Asian countries. The greater weight of indirect taxes in those countries can be explained by the much greater importance of foreign trade in most of those countries compared to that in Pakistan. The weight of indirect taxes in 


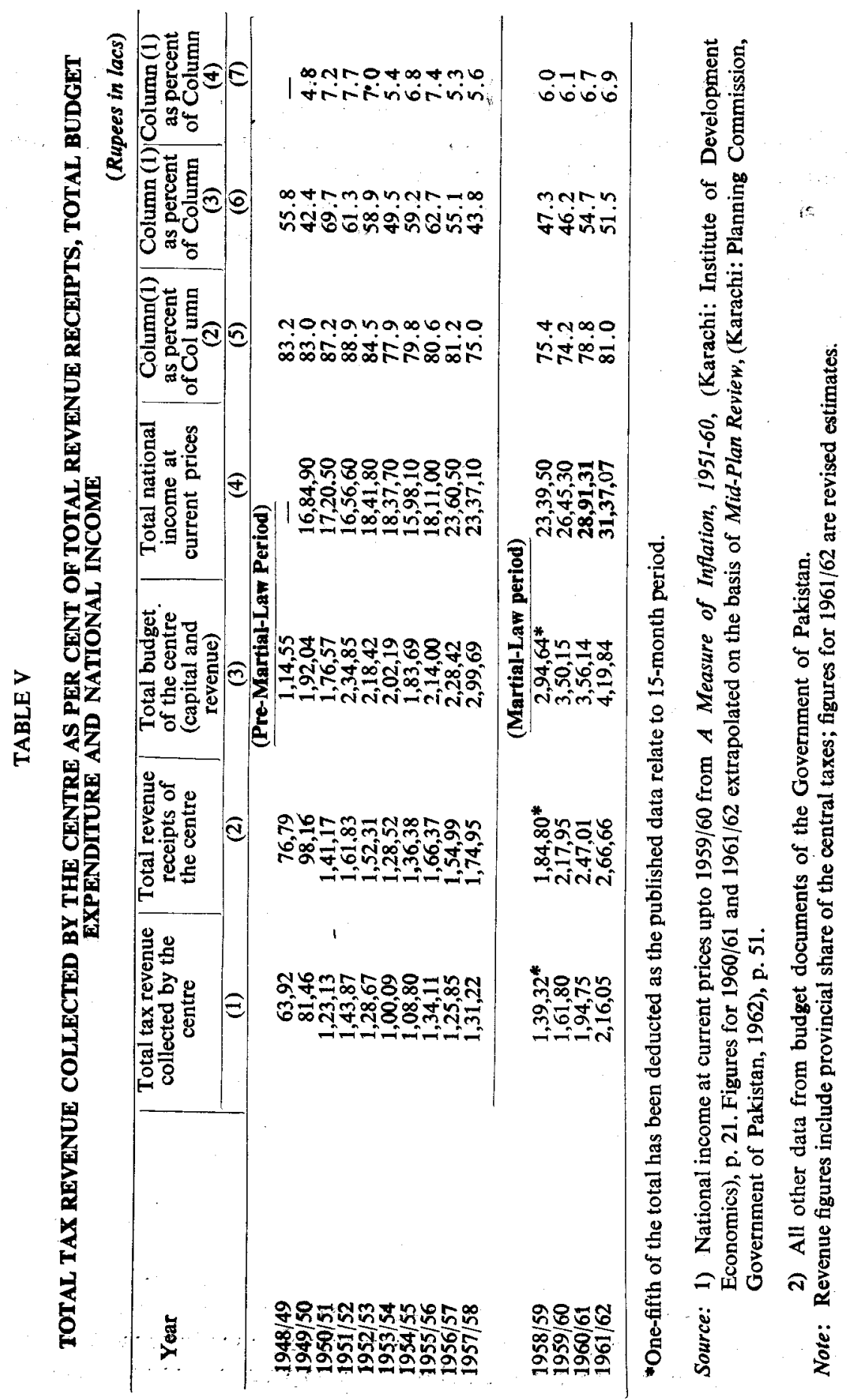


Pakistan is, however, much higher than that in most of the developed countries. Indirect taxes constitute only around 25 per cent of the total tax revenue in the United States, and 43 per cent in the U.K., though in France their share is 67 per cent.

Another characteristic of the fiscal scene in Pakistan is the ever-widening gap between government expenditure and tax revenue. (see, Table V, Column 6)). To meet the defence requirements of the country, to defray the cost of the civil administration and to finance the developmental programme, the government has to spend well near 5 billion rupees. The total tax revenue falls far short-less than 2.5 billion (in 1960/61).

At present, the base of the tax structure remains very narrow. Most of the central taxes are confined to the urban and commercial sector of the economy. The vast subsistence rural sector lies outside the direct jurisdiction of the central tax authorities. Land revenue and agricultural income tax are provincial subjects. For political and administrative reasons, the provinces have failed so far to tap these sources adequately. No successful drive has been initiated to tax the nonmonetized sector. Even in urban and rural monetized sectors, the tax burden has not reached a level commensurate with the demands of a development-oriented society. The central government has been the main agent so far in the collection of taxes in Pakistan. We shall examine the results of its tax efforts a little more thoroughly in the next few pages.

The importance of tax revenue can be viewed from several angles. In Table $\mathrm{V}$, we present the total centrally collected tax revenues as a per cent of three relevant magnitudes: total revenue receipts of the centre, total budget expenditure of the centre (capital and current), and total national income. In Table VII, we consider the changing weights of the individual taxes in the total tax revenue. The period covered is split into two parts, namely, preMartial-Law (1948-58) and Martial-Law (1958-62). The pre-Martial-Law trends are analysed first.

\section{The Position of Tax Revenues during Pre-Martial-Law Period, 1948-58}

a) Total tax revenue as per cent of total revenue receipts: Column (5) of Table $\mathrm{V}$ shows that, prior to Martial-Law, total tax revenue was diminishing in importance in the total revenue receipts of the central government. The percentage declined to 75 in $1957 / 58$ as against 83 in 1948/49. The extent of the decline remains pretty much the same even if we consider the difference between the averages of the first five years and the second five years. If we ignore the bump of the Korean boom period, the ratios form 
a slightly decreasing trend ${ }^{9}$. This down-trend has its counterpart in the greater increase registered by some of the nontax revenue sources, as shown below:

\section{TABLE VI}

GROWTH OF SOME IMPORTANT NONTAX REVENUE DURING 1948-58

(Rupees in lacs)

\begin{tabular}{l|c|c}
\hline Heads of revenue & $1948 / 49$ & $1957 / 58$ \\
\hline Railways & 3,34 & 10,22 \\
Debt services $a$ & 4,94 & 8,99 \\
Currency & - & 3,44 \\
Total nontax revenue & 12,90 & 43,76 \\
\hline
\end{tabular}

(a). Mainly interest on capital in charge of the commercial departments, on loans to provincial governments and interest and dividend on government investment in corporations.

b) Total tax revenue as per cent of total budget: This is presented in Column (6) of Table V. The simple average weight of the total tax revenue in the total budget during the ten-year pre-Martial-Law period is 55.8 per cent ${ }^{10}$. The weight exceeded the average by more than 10 percentage points in only one year of the Korean boom, 1950/51, and fell below the average by more than 10 percentage points in two years, 1949/50 and 1957/58. The heavy increase in expenditure in the latter two years out of inflationary sources may be noted ${ }^{11}$.

The obvious conclusion is that the government could not achieve any headway in the direction of meeting a greater proportion of its expenditure from taxes. Inability to match increased revenue needs from tax revenues forced the government to resort to inflationary sources. It is natural that a government called upon to meet large developmental expenditures is not likely to succeed in raising hundred per cent of its revenue requirements from taxes. But fifty per cent or less, on the other hand, indicates a very

- The ratios of total tax revenue to total revenue receipts of the centre will become lower still if we exclude the share of the provinces in the tax revenue from both the numerators and the denominators.

10. The numerator, total tax revenue of the centre, includes the provincial share of the taxes. If we exclude the provincial share in the taxes, the simple average weight of total tax revenue in the total budget of the centre becomes only 46.6 per cent.

11. Ad hoc treasury bills, drawal on cash balances, and increase in the permanent debt are included in this category. 
poor tax effort. Besides, the volume of developmental outlays by the government was too low to propel the economy towards sustained growth.

c) Total tax revenue as per cent of national income at current prices: The inadequacy of the tax effort in the pre-Marital-Law period appears in sharper relief when total tax revenue is viewed as a percentage of national income. The average level of 'taxation compared unfavourably to those reached in other 'underdeveloped' countries ${ }^{12}$. Table $V$ shows that the weight of taxes was not only low but also had a declining trend during the period under review. The average weight of tax revenue during last four years of the pre-Martial-Law period was less than the average weight during the first four years, whereas the aim should have been to increase this weight. Even if allowance is made for the high level of tax receipts during the Korean boom, the weight of taxes remained rather static. This must be considered very disappointing. The 6- to 7-per-cent figure also probably overestimates the relative tax burden when we consider that the national income figure is believed to be suffering from considerable underestimation. Another discouraging aspect of this low weight of taxes is that it persisted in spite of the appreciable growth in the more heavily taxed sectors.

d) Relative weight of individual taxes in the total tax revenue: The preceding section reveals, that the weight of total tax revenue in the national income was low and stagnant during the period ending in 1957/58. This must have been due to a general inelasticity of the aggregate tax system or to changing weights of different taxes despite an overall elasticity. Table VII is designed to show how the weights of individual taxes were changing in the
aggregate tax revenue.

'Of the five taxes studied, all except the customs gained in weight. This is a desirable trend insofar as the tax revenue becomes free from its extreme dependence on a single source. But this change in the relative weights, it should be noted, is due principally to the decline in customs revenue rather than to a high elasticity of the other taxes ${ }^{13}$. Personal income tax and excise duty showed steady growth over the period. Sales tax became important quite early in the period and remained stable there after. Corporation tax increased quite sharply during the first half of the period but then, declined in relative importance. As for the relative weight of total direct taxes as opposed to the weight of the indirect taxes, the situation significantly altered

12. See, Table III. 13. See, the author's "The Predictability and the Flexibility of Tax Revenues in
Pakistan", Pakistan Development Review, Summer 1962 . 
in favour of the direct taxes. Income and corporation taxes constituted 22.5 per cent of the total centrally collected tax revenues in $1957 / 58$ as against 10.3 per cent in $1948 / 49$.

\section{The Position of Tax Revenues During the Martial-Law Period, 1958-62}

The discussion in the preceding section relates to the. pre-Martial-Law period. The Martial-Law period is considered separately to note any difference that might have been brought about by the new regime.

The figures in Table $\mathrm{V}$ and VII relating to this period do not show any marked deviation from any of the trends indicated earlier. Total tax revenue collected by the centre viewed as per cent of total national income has been steadily rising since $1957 / 58$ but the 6.9 -per-cent figure reached in $1961 / 62$ still remains below that for $1950-53$ or even $1955 / 56$. The magnitude of total tax revenue as per cent of total budgeted expenditure, while it has risen since 1957/58, has remained below its average of the pre-Martial-Law years. This means that, though there has been some growth of tax revenues, this has been slower than the growth of total budgeted expenditure. There has been, however, much greater availability of foreign aid. The increased role played by external resources in financing the expenditure of the government during the Martial-Law period can be seen in Table VIII, where the total external resources received by the government are presented along with the total consolidated capital budget of the central and provincial governments for the years $1951 / 52$ to $1961 / 62$. The amount of external resources received by the governments during 1948-51 was nil. In the very first year of Martial-Law period, external resources received by the government shot up from Rs. 6.5 crores to Rs. 63.0 crores, an increase of Rs. 56.5 crores; while total consolidated capital expenditure increased by only Rs. 31.3 crores. The reduction of inflationary finance by the MartialLaw regime was clearly made possible only by the greater availability of foreign assistance during this period.

Revenues have risen significantly only from excise duties and sales taxes. The collection from personal income tax momentarily boosted up as a result of panic disclosures of hoarded wealth and payments of outstanding arrears giving an appearance of a break with the past trends. Revenues from that source declined, however, after the first year of the Martial-Law period. The decline in the weight of customs, witnessed earlier, continued in this period, as revenues from this source failed to grow proportionately.

In summing up, it may be said that the new regime could not effect much of a changeover in fiscal management in spite of its declared intentions to follow a policy of paying its way through taxes rather than through 


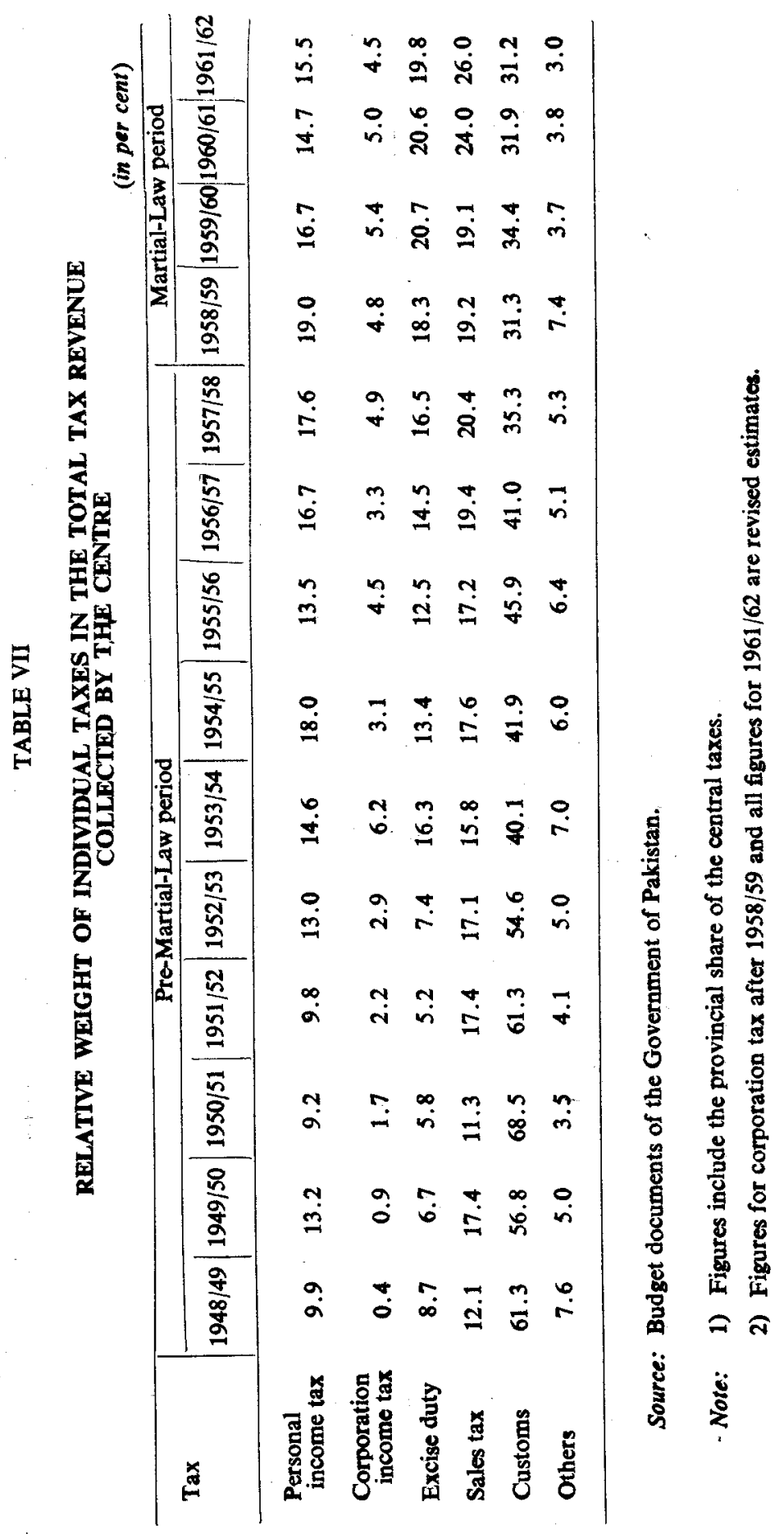




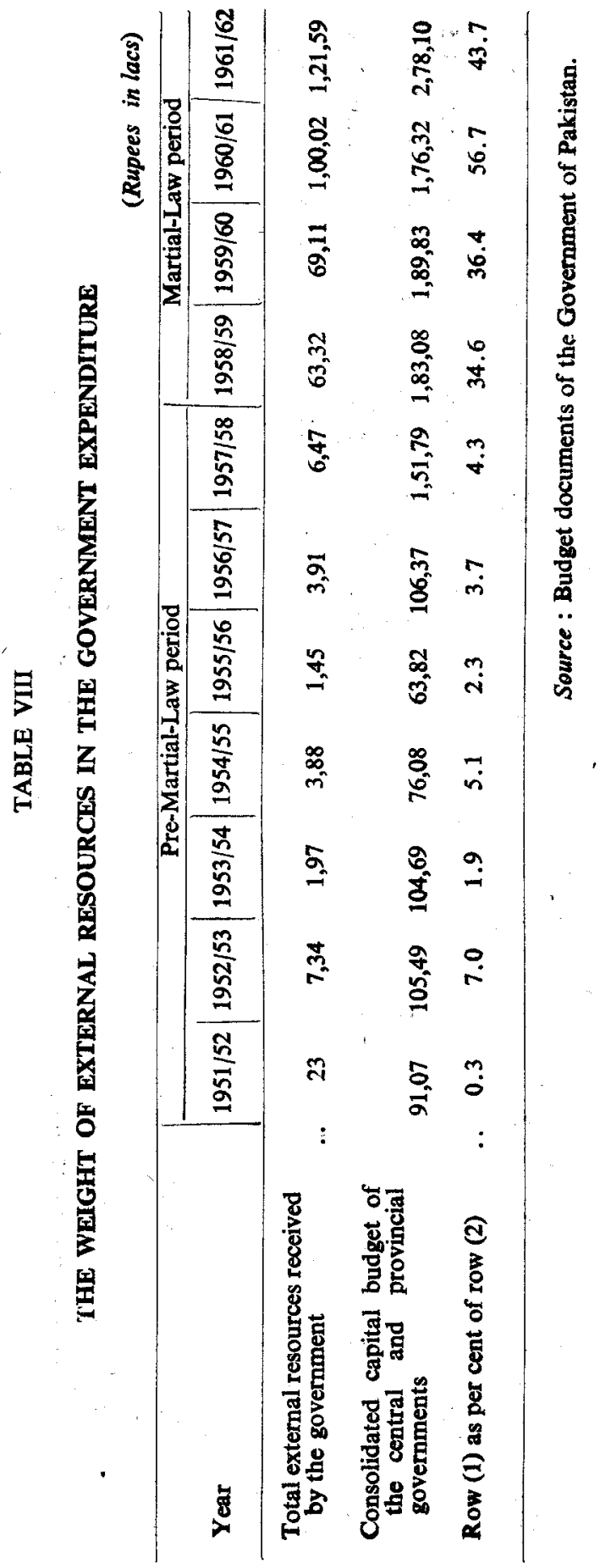


printing of new money. Lack of success in the fiscal front to mobilize resources and a conservative reluctance to use inflationary means kept the new regime also wedded to timid development programmes and heavy reliance on foreign aid. The problem of making taxes a chief instrument for mobilizing domestic resources, thus, remains.

\section{Considerations with Regard to Improving the Productivity of Taxes in Pakistan}

While the foregoing pages depict a grossly inadequate and stagnant tax system, the need for dynamizing it cannot be overemphasized, if the aspirations of economic development are to materialize. The Taxation Enquiry Committee, in its recent report, recognized this need and suggested many alternations in the present tax system. But fringe changes cannot obtain the desired result. What is necessary is a fundamental shift in the assumptions of the tax policy and a transformation of the tax administration. The tax policy should stretch the capacity of the economy to the limit, favour the economically active agents while penalizing the sinecure-holders and should not mince the need for straining groups or sectors-granting that the resources so derived will be put to development efforts that will benefit all in the long run.

The tax-planner in Pakistan confronts many constraints in choosing tax measures, namely, the convenience and capacity of tax administration, effects on the incentive to save and invest, effects on efficiency, considerations of equity and the political power of interested groups. These are constraints which tax-planners everywhere have to face. But the strength and importance of these constraints needs to be interpreted in the light of the special circumstances of the country. The nature of the tax structure and the attainable tax target for Pakistan should be determined on the experience of countries similarly situated and in the context of its special needs and values. When considered in this way, many of the constraints seem less confining.

First, the consideration of saving and investment should be viewed in terms of aggregate saving and investment. A tax may increase aggregate saving even if it reduces private saving if the public propensity to save is higher than the private propensity to save at the margin. Moreover, increased saving in the public sector is necessary at the initial stages of development. In an underdeveloped country savings in the private sector often remain in idle hoards or go to unproductive uses, because inadequate social overhead capital makes investment difficult and unattractive. To a certain extent, greater public saving even at the cost of smaller private saving may 
encourage capital formation ultimately by creating these social overhead and initiating neglected industries.

The need for more public saving should not be viewed just as a pretext for increasing investment in public sector. In an underdeveloped country having no advanced capital market public saving can serve as a substitute for private capital market. Private saving may be accruing in Pakistan to entrepreneurs engaged in certain lines of industries while the social need for new investment lies in other lines of activities with which these savers are not familiar or to which they are reluctant to go. The government can augment public saving by taxing the high profits earned by these entrepreneurs and channel the funds to private investors in other fields.

Second, the concern over incentive to work and efficiency also should be viewed in conjunction with the average living standard of the country. Any income much above the national average is able to bear substantial tax burden without any impairment of the incentive to work or of efficiency. The more relevant problem of incentive is one of maintaining proper income differentials between occupations rather than an absolutely high level of disposable income. To the extent that a higher tax burden falls on people who are currently performing little economic function, taxes can not only succeed in bringing more revenue to public coffers but also encourage the supply of economic enterprise.

Third, indirect taxes can continue to be an effective way of taxing the people without seriously offending the principle of equity. Indirect taxes have been observed to possess some degree of progressivity in the case of underdeveloped countries ${ }^{14}$. The consumption pattern in these countries are such that the lower the income level the fewer are the items of consumption in the family budget over and above the bare necessities of life which are always either duty-free or lightly taxed. Indirect taxes can hit directly at consumption and may be used to provide an equitable distribution of sacrifices in consumption between different income groups. This equity, rather than the equity in distribution of income, is more relevant in the developing countries ${ }^{15}$. Besides, while worrying about equity, the benefits from increased government expenditures must be considered. It should also be remembered that the real choice is often whether to take away the income by taxes, or by printing new money. The former is not only more honest but more wise inasmuch as its impact can be more accurately predicted.

\footnotetext{
14. See, Government of India, Report of the Taxation Enquiry Commission, 1953-54,
l. 1, p. 69 . Vol. 1, p. 69.

15. See, Raja J. Chelliah, Fiscal Policy in Underdeveloped Countries, (London: George Allen and Unwin Ltd., 1960), p. 67.
} 
Fourth, the problem of administrative limitation is often overstressed. Though there is much to be said in favour of simplifying the administration of any tax as far as possible, the productivity of the tax should not always be sacrificed in order to reduce the administrative burden. Rather attempts should be made toward expanding and improving the quality of the tax administration. Development programmes cannot succeed without a developed tax administration behind them. Expenditure on the education and training of tax administrators will fully repay the public treasury. Given these changes in the attitude of the tax-planner and in the quality of the tax administration, Pakistan can hope to raise 15 to 20 per cent of its national income through taxation, a level which has already been achieved by other underdeveloped countries (e.g., Burma, Ceylon).

\section{Some Measures Proposed for Increasing Tax Revenues}

It has been estimated that governments in the underdeveloped countries have to mobilize 20 per cent or more of GNP to meet its capital and current expenditure, depending upon the role that government is required to play in providing investible finance for economic development ${ }^{\mathbf{1 6}}$. In Pakistan the consolidated revenue budget of the central and provincial governments accounted for 10 per cent of national income both in 1960/61 and 1961/62. The consolidated capital budget amounted to another 6 per cent of national income in 1960/61 and 9 per cent in 1961/62. So it appears that Pakistan also needs to mobilize in taxes some 20 per cent of GNP to finance the government expenditures mainly through taxes and to compensate for low private saving in the economy. This means increasing the relative weight of taxes in the national income of Pakistan almost threefold. A very aggressive and well conceived tax policy is called for to achieve such an ambitious target. We shall conclude this paper with some broad suggestions on possible fiscal measures in the context of particular taxes in Pakistan and with an appraisal of their revenue prospects.

\section{Direct Taxes}

Not having a large export sector makes it 'necessary for Pakistan to raise the yields of the direct taxes. Of the direct taxes again, the main emphasis has to be on personal income tax and corporation tax. Direct taxes on capital and wealth cannot raise a significantly large proportion of national income in revenue, because Pakistan, an underdeveloped country, is by definition, a capital-poor country. Wealth taxes may be levied on grounds

16. See, A.M. Martin and W.A. Lewis, "Patterns of Public Revenue and Expenditure", The Manchester School of Economic and Social Studies, September 1956, p. 218. 
of equity and to check against evasions of the income tax and their yield can be increased substantially over their present level. But it is on personal income and corporation taxes that reliance must be placed to collect a very high proportion of GNP.

The present coverage and the average rate of personal income tax in Pakistan are very inadequate. The number of persons assessed to pay income tax is less than .1 per cent in Pakistan whereas it is around 25 per cent in the United Kingdom and in the United States. Again, persons earning similar levels of income in Pakistan bear a considerably lower tax burden compared to their foreign counterparts until they reach very high levels of income-this in spite of the fact that the relative position of the persons earning the same income is much higher in Pakistan.

The reasons usually given for the narrow coverage and low average rate of the personal income tax in poor countries are as follows ${ }^{17}$. It is thought that the poor countries have to tax relatively more people to raise the same proportion of the GNP. The cost of collection is too large compared to the small collections made from the average assessees. Rates on the lower and middle income grades have to be moderate because these groups bear relatively greater burden of providing for the education of their dependents.

The reasons mentioned above are largely based on some misconceptions, and the truth contained in them cannot account for the wide differences in the burden of income tax between persons in the underdeveloped countries and the developed countries. First, inequality of income distribution in Pakistan is perhaps greater than that in many developed countries. So Pakistan can raise the same proportion of GNP by taxing relatively fewer people. Second, the importance of higher unit cost of collection is often exaggerated. Low average collection is partly matched by the low average salary of the tax collectors. This constraint will be further relaxed when the average rate of tax is increased. Third, indiscriminate tax concessions to everybody is not a happy way to provide relief to those who have to pay for the heavy educational expenses of their dependents. For this, special allowances can be made. But a more effective way to handle this is liberal provision of scholarships and subsidized education in socially desirable lines. This will, at the same time, reduce the common spectacle of a poor man's meritorious ward going without proper education while money is being wasted on worthless sons of the well-to-do. Altogether there seems no strong case for not making the coverage and the average rate of personal 
income tax comparable to those in developed countries, but the need for doing so is far greater here.

\section{Indirect Taxes}

The narrow base for many of the direct taxes plus administrative limitations in underdeveloped country has made use of indirect taxes attractive. Pakistan also cannot neglect this expedient. But since the volume of foreign trade is low the prospects of raising more revenue from export and import duties is dim. Heavier taxes on domestic trade is another alternative.

We suggest the adoption of a comprehensive sales $\operatorname{tax}^{\mathbf{1 8}}$. For this, commodities may be classified under three broad categories. Category one would contain the basic necessities which weigh heavily in the average family's budget, and whose prices must be kept from rising if reasonable stability in the cost of living is to be achieved. These would be tax free and their supply would have to be expanded to accommodate increased demand if prices are to remain more or less stable. Category two would consist of semi-necessities. A moderate sales tax of about the present level should be levied on them. Normal elasticities of supply and demand should be allowed to determine the equilibrium prices of commodities in this group. Category three would cover all luxuries and socially undesirable commodities. Prices of these things should be allowed to soar to their equilibrium freemarket level with supply fixed. The sales tax on this group should be designed to take away all of the excess profit so that there is no tendency on the part of private entrepreneurs to expand their supply. The actual rate of $\operatorname{tax}$ to be charged could be arrived at theoretically from knowledge of the income and price elasticities of demand for these commodities. The list of commodities in each category should be prepared on the assumption of a really tough policy towards consumption, keeping in view the average level of living in the country. Expansion of the domestic market of a commodity in the third category may be allowed only in a case where this is necessary for the sound growth of an industry with a big export potential ${ }^{\mathbf{1 9}}$.

The two taxes dealt with so far touch mostly the industrial-urban sector. Because of relatively less monetization in the rural sector and noninclusion of agricultural income for the assessment of personal income tax, the rural sector of the economy where the major portion of national income accrues remains relatively unscathed by the tax proposals made above. Neverthe-

18. "If an underdeveloped country needs to raise some 15 to 20 per cent of GNP in revenue and cannot rely heavily on a large yield from taxing foreign trade, the adoption of some form of a sales tax is inevitable", Ibid, p. 227.

10. This scheme for a sales tax for Pakistan follows suggestion made by Dr. John H. Power, a Research Adviser in the Institute. 
less, this emphasis on taxing the urban sector has some important advantages. First, it favours a high incremental saving ratio as income rises more rapidly in the urban sector. Second, insofar as urban consumption tends to have a high import content, this will yield more saving on foreign exchange. Third, restriction of urban consumption demand, especially of luxuries, will force industrial profits to be invested more in capital-goods industries, as well as in essential consumption-goods industries.

\section{Agricultural Taxation}

A poor country must look ultimately to its agriculture, however, for the economic surplus necessary to finance development. Here is where most of the national income is generated and here is where the labour supply for industrialization largely originates. The growth of the industrial labour forces must be matched, at least in part, by a flow of saving from agriculture. At present, a sizeable transfer occurs through the maintenance of adverse terms of trade for agriculture and the overvaluation of the rupee. But at the same time, agricultural taxation has lagged and has failed to mobilize fully the economic surplus which is being augmented by agricultural improvements and overhead investments undertaken by the government. Moreover, adverse terms of trade tend to discourage production and encourage consumption of agricultural output in rural areas, while it is the reverse that is needed. In short, there is a greater role for tax policy to play in mobilizing agricultural resources for development.

Clearly, a greater contribution from agriculture depends primarily on increased output. This, in turn, may require rather fundamental changes in the organization of agriculture. While extreme measures like collectivization of agriculture are detested in our country, a reorganization of our agriculture on the generally approved principles of cooperation should be feasible ${ }^{20}$. This could be highly rewarding from the point of view of both resource mobilization and productive efficiency: The energies of all the government and government-sponsored agencies currently engaged in agriculture might be joined into one comprehensive agency to make this changeover successful.

Until such a thorough-going solution is possible, attention should be concentrated on removing the slack in the taxation of agriculture. The

10. A case for cooperative farming in India is presented in M.A. Khusro and A.N. Agarwal, The Problem of Cooperative Farming in India, (Bombay: Asia Publishing House, 1961), pp. 140. The prospects of cooperative methods in the Pakistan agriculture are highlighted by the success recently achieved in a rural cooperative pilot experiAcademy for Village Development, Comilla. 
primary emphasis should be on land taxation, since by increasing the cash needs of the farmers and penalizing unproductive use of land, both production and marketing are encouraged. In addition, means must be found for implementing income taxation in agriculture to curb the consumption of the high-income recipients.

The measures suggested above are subject to stupendous political and administrative constraints. The author has no illusions in this respect. The measures are not tipped because the political and administrative matrix is all set for them. This paper is an attempt to show the leeway in the fiscal front, the magnitude of the tax efforts we need to make, and the possible directions and emphasis of the tax policies. Once these are found convincing, the constraints may start loosening. It may come to be considered worthwhile to build up a tax administration which is more business-like, has different emphasis on the qualifications of its personnel and is subject to a separate discipline. A political elite having mass support may identify itself with the cause of rapid economic development. It may agree to make sacrifices and dare to offend interested groups who have to be hurt in the short run. Again, all these may have to be preceded by the generation of that 'popular enthusiasm' which has been termed by Professor Lewis as "both the lubricating oil of planning, and the petrol of economic development"21.

1. W.A. Lewis, The Principles of Economic Planting, (London: Allen and Unwin Ltd., 1949), p. 128. 